\title{
HYPOCOGNITION AND THE INVISIBILITY OF SOCIAL PRIVILEGE
}

\author{
Kaidi Wu and David Dunning
}

\begin{abstract}
Purpose - Are members of socially dominant groups aware of the privileges they enjoy? We address this question by applying the notion of hypocognition to social privilege. Hypocognition is defined as lacking a rich cognitive or linguistic representation (i.e., a schema) of a concept in question. By social privilege, we refer to advantages that members of dominant social groups enjoy because of their group membership. We argue that such group members are hypocognitive of the privilege they enjoy. They have little cognitive representation of it. As a consequence, their social advantage is invisible to them.

Approach - We provide a narrative review of recent empirical work demonstrating and explaining this lack of expertise and knowledge in socially dominant groups (e.g., White People, men) about discrimination and disadvantage encountered by other groups (e.g., Black People, Asian Americans, women), relative what members of those other groups know.

Findings - This lack of expertise or knowledge is revealed by classic cognitive psychological measures. Relative to members of other groups, social dominant group members generate fewer examples of discrimination that other groups confront, remember fewer instances after being presented a list of them, and are slower to respond when classifying whether these examples are discriminatory.

Social Implications - These classic measures of cognitive expertise about social privilege predict social attitude differences between social groups, specifically whether people perceive the existence of social privilege as well as believe discrimination still exists in contemporary society. Hypocognition of social privilege also carries implications for informal interventions (e.g., acting "colorblind") that are popularly discussed.
\end{abstract}

Advances in Group Processes, Volume 37, 1-23

Copyright (C) 2020 Emerald Publishing Limited

All rights of reproduction in any form reserved

ISSN: 0882-6145/doi:10.1108/S0882-614520200000037001 
Keywords: Hypocognition; intergroup relations; social privilege; racial discrimination; gender discrimination; Asian Americans

\section{HYPOCOGNITION AND THE INVISIBILITY OF SOCIAL PRIVILEGE}

The United States faces ever-deepening social divides. A 2016 Pew Research Center report shows that a majority of Black People perceive racial discrimination in everyday living, but less than half of White People agree. Among White People, perception of anti-White bias has dramatically increased, along with a belief that ethnic minorities now enjoy racial privileges (Pew Research Center, 2016; Phillips \& Lowery, 2018). Attitudinal chasms have widened not only along racial lines but also between genders. In the wake of the \#MeToo movement, $41 \%$ of women state that men have easier lives than women, whereas only $28 \%$ men state similarly. Among those who support the opposite view that men these days have harder lives than women, men are strikingly three times more likely than women to say so (Pew Research Center, 2017).

Why do people from traditionally dominant social groups in the United States, such as men or White People, perceive there to be less discrimination aimed at subordinate groups relative to what subordinate group members believe? In contemporary terms, why do members of dominant social groups see less privilege in their lives than that perceived by subordinate groups? To be sure, discrimination and prejudice still exist in contemporary society, and is observable and measurable (Bleich et al., 2019; Blendon \& Casey, 2019; McMurtry et al., 2019; SteelFisher et al., 2019), so why do people differ in their belief of its extent, or whether it exists at all?

In this chapter, we propose that dominant groups do not necessarily deny or actively "cloak" their privilege. Instead, we argue that such groups fail to acknowledge social privileges because those privileges are often invisible to those who have them. If people do not have to deal with discrimination on a day-to-day basis, they do not know that its absence is an advantage that they enjoy.

We argue that people from dominant social groups suffer from hypocognition, or the absence of a cognitive or conceptual representation, of social privilege (Wu \& Dunning, 2018). They may have only a hazy impression surrounding the concept of their privilege, failing to have rich, detailed, and integrated knowledge of the disadvantages suffered by others. They fail to see privilege because they carry only an impoverished representation of the concept, relative to those for whom it is a visible fact of everyday life. They lack awareness or understanding of the scope, type, and frequency of prejudice that disadvantaged groups face in contemporary society and how those disadvantages tie together. They have only sparse historical knowledge of past discrimination and its consequences (Nelson, Adams, \& Salter, 2013). As such, they lack the cognitive architecture necessary to identify their privilege - they fail to recognize instances of someone else's disadvantage, to remember it, to recognize its significance, to acknowledge its prevalence and systemic nature, or to enter discussions of it. 
We discuss hypocognition of privilege to account for asymmetries in perception of privilege and discrimination found across social groups and to explain why conversations across those groups often falter. We describe cognitive and social consequences of hypocognition. In addition, we ask if alleviating hypocognition can increase awareness of privilege and encourage recognition of the prevalence of discrimination. We end with a discussion on interventions that make visible the scope of discrimination experienced by subordinate social groups. At the same time, we caution against "privilege checking" and address situations in which confronting privilege can evoke identity-defensive motivations and backlash (Egan Brad, Spisz, \& Tanega, 2018; Unzueta \& Lowery, 2008).

To begin, we must define the terms of social privilege and hypocognition.

\section{WHAT IS SOCIAL PRIVILEGE?}

Social privilege is commonly defined as the rights or advantages that people of dominant social groups receive as a consequence of their group membership (Black \& Stone, 2005). Although the concept of social privilege dates back to the nineteenth century, a resurgence of interest emerged in the 1980s among feminist scholarship. In her seminal work on White Privilege, women's studies scholar Peggy McIntosh (1989) likened privilege to an invisible knapsack of "special provisions, maps, passports, codebooks, visas, clothes, tools, and blank checks."

Key to our analysis, advantages related to one's social privilege are as much about the absence of everyday burdens as they are the presence of conveniences. Many advantages included in the invisible knapsack of White Privilege (McIntosh, 1989), for example, point to the lack of hassles White People have to worry about, such as not being followed when shopping and not being asked to speak for people of their race. This absence of inconveniences is a fundamental part of what makes privilege invisible, what dominant social groups fail to perceive, and what makes dominant groups hypocognitive of their advantaged circumstance. Although it is easy to appreciate the mosaic of diverse social worlds, it is far more difficult to traverse the landscapes of differing social categories and personally experience them. It is rare, if not impossible, to live life as both White and non-White, male and female, able and disabled, straight and gay, or right- and left-handed. Hence, dominant social groups do not readily recognize the advantage attached to not worrying about discrimination (Sidanius \& Pratto, 1999), inequality (Kraus, Rucker, \& Richeson, 2017), harassment (Fairchild \& Rudman, 2008), and poverty (Bullock, 1999) as an inherent aspect of their social privilege, because they do not frequently experience and cannot conceive of concrete instances of difficulties borne by subordinate group members. Those instances and their prevalence remain invisible to them.

There is another aspect of social life that makes such advantages invisible to the dominant group while making disadvantage observable to subordinate ones. The lives of people in dominant social groups are more salient in the mainstream culture. Their experiences are implicitly regarded as prototypical and normative (Sidanius \& Pratto, 1999). Their lives are embedded in norms and attitudes that 
are so pervasive that they become invisible. These folkways and experiences become like water so ubiquitous to the fish that the fish never notices it. Standing somewhat on the outside, people from subordinate groups are more acutely aware of the social conditions and life experiences of those from dominant groups than vice versa (Pratto, 1991).

\section{WHAT IS HYPOCOGNITION?}

We describe the absence of cognitive representation for one's social privilege as the hypocognition of social privilege (Wu \& Dunning, 2018). The term hypocognition has a rich and vital history in anthropology and linguistics. It was originally coined by anthropologist Robert Levy (1973) to describe the phenomenon in which people lack the cognitive or linguistic representations of concepts to understand or interpret emotional experience. More specifically, Levy found that Tahitians explicitly described no grief when they suffered the pain and loss of their loved ones, because they are had no conception, or were hypocognitive, of the emotion. To be sure, they experienced some aspects of grief, but at a conscious level could not describe it completely or accurately. Instead, they only describe their emotion as feeling "sick" or "strange."

In cognitive psychological terms, hypocognition can be thought of as the absence of being schematic for a concept (Bartlett, 1932; Neisser, 1976). As classically defined, a schema is a well-established knowledge structure containing features representing a concept and associations with it (Barsalou, 1983). For example, most people have a schema of an apple, knowing that it is red, round, a fruit, edible, and sweet.

Schemata are the workhorses of competent cognitive function (Bartlett, 1932; Neisser, 1976). They allow people to make inferences and predictions about the objects, people, and events they encounter. Schemata direct attention and assist the absorption of new information. They aid memory, although they sometimes inspire false memory, distorting accounts of past events to better fit the schema (e.g., a green apple may be misremembered as being red). They aid conversation: Imagine an American talking baseball to a European or a European talking soccer back to the American. A chat would not go smoothly if one person had few associations to the ideas the other person expressed. A schema also includes elaborations on how a concept connects with other concepts. For example, to be schematic of the concept of depression is not only knowing the label of a mental disorder and its features but also being aware of people's attitudes toward mental illness or ideas associated with therapy (Alba \& Hasher, 1983; Brewer \& Treyens, 1981).

To be hypocognitive, or lacking schematicity, is to have an impoverished knowledge structure that contains only fragmentary aspects of a concept with few associations among its features. Although they may know their apples, most US Americans have little knowledge of a durian, a common fruit found in southeast Asia. Americans lack conceptual knowledge of its look, taste, smell, and use. They are not aware that the fruit is yellow with a spiky husk, has a sweet flavor and a creamy texture, and often provides a memorable and overpowering odor. 
In fact, we suspect that many people have no idea that such a fruit exists. In our work, we find that when Americans are quizzed about the fruit, they have no network of associations needed to remember seeing it when presented or to discern it from other fruits (Wu \& Dunning, 2019).

We extend the notion of hypocognition to examine it as a cognitive blind spot in why and how people fail to acknowledge their privilege and the discrimination experience of subordinate social groups. To them, the hypocognition of privilege is like the impoverished experience of a durian: When asked about the fruit, they have little conceptual knowledge of its features. Conversely, when given a list of a durian's features, they would not know that those features connect to describe a specific type of fruit.

As an illustration of this last point, consider the following objects: scissors, school desks, spiral notebooks, guns, can openers, guitars, and measuring tape. What category do these objects represent?

The answer is that they are all objects typically designed for right-handed people and which present problems for those left-handed. Left-handers frequently have to fumble with scissors meant to be used in their nondominant hand. They have to write on classroom desks designed for the comfort of right-handed individuals. Whereas this theme may be readily identifiable among left-handers, it is likely hypocognized among right-handers, who do not need to worry about finding tools designed for them in everyday living. In short, right-handers do not know the privilege that their handedness confers.

In our work, we have demonstrated that right-handers, indeed, have more impoverished conceptual knowledge for struggles faced by left-handers. When we asked people to list daily inconveniences left-handers experience, right-handers generated fewer instances than left-handers. This lack of conceptual knowledge for the hassles of the left-handed, in turn, explained right-handers' lack of acknowledgment of the privilege they have in the way that tools are designed, as well as the comparative burdens that left-handers face.

\section{Hypocognition of Male Privilege}

What about privileges conferred by membership in other social categories? In The Macho Paradox (2006), educator Jackson Katz described a classroom exercise during which he drew a line down the middle of a chalkboard and asked men and women to write down on each side of the board the steps they would take to prevent being a victim of assault. Whereas the instruction was followed by an awkward silence among men, women readily recounted safety precautions as a part of their daily routine (e.g., "holding my key as a potential weapon," "always carry a cell phone"), quickly filling up their side of the chalkboard.

Our data echo Katz' classroom demonstration and show that hypocognition underlies the invisibility of male privilege. We exposed men and women to a list of safety precaution items (adapted from Katz, 2006; Table 1). Afterward, we asked men and women to recall as many of the safety precautions on that list as they could. In the presentation phase, there were filler items (e.g., turn off the faucet when brushing teeth) interspersed with the safety items. In the recall phase, 
Table 1. Safety Precaution Items from Katz (2006).

\author{
Own a big dog \\ Vary one's route home from work \\ Hold one's key as a potential weapon \\ Watch what one wears \\ Park in well lit areas \\ Guard one's drink \\ Share one's location with a trusted friend \\ Check the backseat before getting in one's car \\ Avoid getting on an elevator with a lone man \\ or group of men \\ Have a male voice on one's answering \\ machine \\ Avoid renting first-floor apartments \\ Book flights that arrive during the day \\ Pretend to be on the phone when walking \\ home \\ Go out in groups \\ Be careful not to drink too much \\ Watch one's drink being poured \\ Share one's itinerary with family and friends \\ Lock car doors as soon as one gets in the car \\ Avoid wearing headphone when jogging \\ Meet first dates in public areas
}

the instruction did not explicitly mention "safety" items; rather, it asked participants to recall all items to the best of their ability. If men have a stronger conceptual grasp of male privilege in relation to the absence of inconveniences they have to carry (e.g., worry about self-protection against assault), they should be better able at recalling its associated instances. On the other hand, if men have poorer conceptual knowledge of safety precautions borne by women, they may only be able to see them as disparate pieces and show poorer memory of such precautions. Indeed, we found men recalled fewer safety precaution items compared to women. Note that men and women did not differ in their recall of filler items, suggesting that our finding of memory degradation among men (vs women) was due to hypocognition, not gender difference in memory ability.

Hypocognition of male privilege manifests not only through the lack of schematicity of self-protection against assault, but more broadly, through a lack of conceptual knowledge of everyday gender discrimination. When asked to freely generate instances of everyday discrimination instances women have to navigate (e.g., being catcalled, being told to smile by strangers on the street), men came up with fewer instances than women.

We further assessed how hypocognition of male privilege relates to opinions about male privilege and gender discrimination. We found that, overall, men were less aware of male privilege (e.g., "Men have it easier than women," adapted 
from Pinterits, Poteat, \& Spanierman, 2009) than women. Hypocognition (e.g., failure to recall safety precaution items or generate instances of gender discrimination) predicted this gender gap in awareness of male privilege. We also asked people to rate the extent of gender discrimination faced by men and women, respectively, from 1950s to 2010s (Norton \& Sommers, 2011). Men, compared to women, perceived much less gender discrimination against women (vs men), especially in recent decades. This gender difference in perceived discrimination was accounted for by men's hypocognition of male privilege.

We have also measured hypocognition of male privilege via schematicity of beyond the topic of safety precautions (or lack thereof). In another study, we measured hypocognition via a free generation procedure in relation to gender discrimination more broadly. We asked men and women to generate as many daily hassles related to gender discrimination as they could think of. Replicating the previous study, we found that men were unable to generate as many gender discrimination instances (e.g., being explained things to them (that they are expert of) by a man; having doctors doubt or dismiss their pain) as women. This lack of schematicity (absence of inconveniences), again, predicted men's reduced perception of male privilege and gender discrimination.

\section{Hypocognition of White Privilege}

Much like handedness advantage and male privilege, hypocognition can underlie the invisibility of racial privilege. In a series of studies, we have found that White Americans are hypocognitive of White privilege, lacking the conceptual knowledge needed to identify, remember, generate, and react to instances of racial discrimination that their non-White counterparts have to navigate. White People lack a set of interconnected ideas representing a rich conceptual network that would help them remember, generate, or make judgments about the notion of privilege. For example, after being presented with a list of everyday instances of discrimination (e.g., being told jokes about the way they speak, being asked where they are really from), White People recalled fewer of the instances than Asian Americans in an unexpected memory recall task a few minutes later. In addition, when asked to freely generate instances of discrimination, White People came up with fewer examples.

White Americans also show signs of hypocognition relative to Black Americans when it comes to instances of racial discrimination as experienced by Black People. For example, White People were not able to generate as many examples of discrimination, relative to Black participants, when asked to list as many instances as they could. In another study, after being presented with a list of discriminatory behaviors (e.g., being suspected as loiterers at a coffee shop, calling the police for assistance but being suspected to be the criminal when the police arrive) and a few minutes later asked to recall as many behaviors as they could, White People recalled fewer of them than Black People.

If White Americans have less conceptual knowledge of what White privilege entails, it should come as no surprise that they are less aware of their privilege (Pratto \& Stewart, 2012) and underperceive racial discrimination (Norton \& Sommers, 
2011). Indeed, our studies demonstrated that hypocognition among White People mediated group differences in acknowledging White privilege and perceiving the extent of discrimination faced by both Asian Americans and Black Americans. Specifically, White Peoples' lack of conceptual knowledge of the discrimination experience borne by non-White People predicted their lower awareness of White privilege and lower perception of racial discrimination, particularly in recent decades.

One caveat in interpreting evidence for hypocognition of social privilege is that we do not imply that members from socially dominant groups face no obstacles in life. We acknowledge that each group faces difficulties related to their social category, and that each group may have their respective blind spots of difficulties encountered by other group(s). For example, women may be unaware of certain struggles men face, such as the need to stay strong and hold back emotion. However, our studies highlight systemic manifestations of discrimination and absence of social privileges enjoyed by dominant group members. A 2019 Pew report shows $76 \%$ of Black Americans and Asian Americans report facing discrimination in the United States, a statistic that far exceeds that of White Americans. Ironically, many White Americans today fail to acknowledge their White privilege and claim to suffer from "reverse racism" (Phillips \& Lowery, 2015, 2018), despite that two-thirds of White People report never experiencing discrimination (Pew Research Center, 2019). Our studies demonstrate the cognitive process underlying dominant group members' hypocognition of privilege and link such hypocognition to gaps in discrimination attitudes.

\section{WHY DOMINANT GROUPS ARE HYPOCOGNITIVE OF THEIR PRIVILEGE}

Several psychological dynamics conspire to make social advantage invisible and the people who enjoy them hypocognitive to those advantages. If one does not have to face discrimination in one's own life, one can remain blissfully unaware of that discrimination and its prevalence. People cannot be expected to be expert in that which they fail to experience - at least not as expert as those who frequently encounter those experiences.

\section{Attention Is Given to Obstacles More Than Aids}

People in general attend to the barriers that they have to overcome more than the blessings they enjoy. In other words, headwinds are more salient than tailwinds (Davidai \& Gilovich, 2016). This headwind/tailwind asymmetry has been documented in various contexts: Democrats and Republicans both see the electoral map working more against them than for them; academics think they face more hurdles than their colleagues in other subdisciplines; people believe they have faced harsher parental treatment than their siblings.

Notably, it is not that people are merely self-serving. In a trivia contest, people actually remembered more difficulties stacked against them than their opponents 
instead of just claiming them (Davidai \& Gilovich, 2016). Barriers require attention to overcome and demand effort and cognitive resources. They take the central focus of our attention, thus remain rooted in our memory, and leave fewer cognitive resources to note the privileges we enjoy. Hence, it is all too easy to notice the difficulties one has to overcome and to ignore the structural advantage one has been granted, the role of luck in one's success, and the systemic challenges faced by others (DiAngelo, 2018; Frank, 2016; Mullainathan \& Shafir, 2013).

However, if this availability bias in assessing one's headwind versus tailwind pervades everyday living and occurs to people of all social groups, why are ascendant groups particularly blind to their privilege relative to subordinate groups?

\section{The Dominant Is Normative}

Part of the privilege of having a socially dominant group identity is not having to be aware of one's identity and the privilege it carries. Because the lives of members from socially dominant groups are more available than those of members from subordinate groups, the dominants are viewed as the normative standard against which to compare others (Pratto \& Stewart, 2012). People from dominant groups fail to see their identities as privileged because their group identities are often regarded as neutral and unmarked. Their circumstances recede into the background.

According to norm theory, people bring to mind exemplars of a category when given a category label. They do so by mentally aggregating features of exemplars to form a prototype, which is a type of schema that describes categories (Kahneman \& Miller, 1986). For example, when given the category label "U.S. president," people are likely to generate a prototype of a White male because all but one U.S. presidents have been White and male (Pratto \& Stewart, 2012). Any example that goes against the normative standard (e.g., Barack Obama) is an anomaly - and any features that contrast with the norm (e.g., race) stand out - whereas any features of exemplars that fit the norm (e.g., being White/male) are not noted and go unexplained. Implicit mental norms can be so widely accepted that it is not only the dominant groups who identify the dominant group category as the default. For example, when asked to think about the national category "American," White Americans associate "American" with "White." Asian Americans, too, showed such association (Devos \& Banaji, 2005).

Whereas people from dominant groups may be oblivious to their group identities, people from subordinate groups have to be aware of what their identities entail (Pratto \& Stewart, 2012). Because subordinated identities carry features that deviate from the norm, their identities are viewed as anomalies that need to be explained against the normative standard (Pratto, Hegarty, \& Korchmaros, 2008). For example, when asked to explain gender difference in voting behavior or a gender gap in illness rate of college professors, people emphasize the qualities of women rather than men. In contrast, when asked to explain gender gaps in illness rates of elementary school teachers, the prototype of which tends to be female, 
people emphasize the qualities of men (Miller, Taylor, \& Buck, 1991). The emphasis on deviant groups occurs beyond gender categories. When asked to write down explanations for differences between straight and gay men, people focus on attributes of gay men (Hegarty \& Pratto, 2001).

\section{Power Makes People Blind}

People from dominant social groups are not only viewed as the normative standard, they also tend to hold more power in society. Holding more power means one can be inattentive to the circumstances of others. Because the powerful do not depend on societal resources or other people as much as the powerless, they need not "individuate down" as much as people on the lower end of the hierarchy need to "individuate up." They need not attend to the details of social life. As such, they are more likely to stereotype subordinate groups and neglect stereotype-inconsistent information about the individual (Fiske, 2001; Goodwin, Gubin, Fiske, \& Yzerbyt, 2000). The powerful also need not appease people below them by attending to their moods or being sensitive to their needs to optimize interpersonal interactions (Henley, 1977). Further, the powerful show more nonverbal cues of disengagement (e.g., fidgeting with object, self-grooming) and fewer signs of engagement (e.g., head nods, laughs) when interacting with a stranger (Kraus \& Keltner, 2009). Indeed, a metaanalysis has found that people who are powerful, dominant, or of high status exhibit fewer signs of attentiveness (e.g., smiling, expressive face) in general when speaking (Hall, Coats, \& LeBeau, 2005).

Much research has examined the behaviors of the powerful in relation to people with class privilege. People who belong to a higher social class have been shown to be less empathetic and less attuned to other people's psychology. Upper-class people score lower on dispositional measures of compassion than lower-class people. They react with less compassion to the suffering of others (e.g., a video of children living with cancer; Stellar, Manzo, Kraus, \& Keltner, 2012). Physiologically, upper-class people do not show as much heart deceleration - a measure of attunement with others - as do lower-class people in response to others' distress. Further, people of higher social class score lower on empathic accuracy. They judge the emotions of a partner less accurately and are less accurate in inferring emotions from muscle movements around the eyes (Kraus, Côté, \& Keltner, 2010).

One of the reasons people of higher social class attend less to others is that other people do not present as a reward or threat, and thus are not worth attending to. One study had pedestrians walk down a block in New York City wearing Google Glass (Dietze \& Knowles, 2016). People who categorized themselves as belonging to a higher social class gazed less at fellow pedestrians on the streets compared to those who self-categorized into a lower social class. Further, experimental evidence confirms that inducing power decreases paying attention to the perspectives of others (Galinsky, Magee, Ena Inesi, \& Gruenfeld, 2006). One study primed power by asking people to think about a time when they had power over others (vs being powered over by others). It then asked participants to draw an E on their forehead. The more power participants reported having, the 
more likely they drew an $\mathrm{E}$ in the direction as if they were reading it themselves (vs drawing an E backward legible to other people reading it).

\section{IGNORANCE OF HISTORY}

Our analysis asserts that dominant groups lack adequate conceptual knowledge to recognize and remember social privilege. If asked to describe the discrimination suffered by other groups, they have little cognitive architecture of associations to draw on. However, another reason that dominant group members fail to acknowledge their privilege is that they fail to know history. That is, in addition to lacking conceptual knowledge of the ideas that underpin notions of "privilege" or "prejudice," they also fail to know relevant historical facts. They fail to have the knowledge necessary to accurately comprehend the scope of discrimination endured by subordinate group members across history, and this ignorance may underlie group difference in perception of racism (Nelson et al., 2013). This is known as the Marley hypothesis, reflecting the song lyrics from Bob Marley's "Buffalo Soldier": "If you know your history/then you will know where you're comin' from/and you wouldn't have to ask me/who the heck do I think I am."

The Marley hypothesis, with its focus on simple ignorance, contrasts with two alternative motivational accounts explaining why dominant group members perceive less discrimination than subordinate group members. The first motivational account suggests that subordinate group members exaggerate group differences to gain special treatment and justify gaps in achievement (Feagin \& Sikes, 1994; Strickhouser, Zell, \& Harris, 2018). The second motivational account suggests that dominant group members intentionally "cloak" their privilege and downplay the reality of discrimination to assuage their guilt about their privilege and unearned advantages (Adams, Tormala, \& O’Brien, 2006; Phillips \& Lowery, 2018; Unzueta \& Lowery, 2008).

The Marley hypothesis provides a differing perspective based on cognition rather than motivation: It is not that minority group members are motivated to "play the race card" (Wise, 2006); nor do dominant group members necessarily engage in intentional blindness. Rather, people from dominant groups lack knowledge to recognize the sweep of discrimination across history. To gauge historical knowledge, Nelson et al. (2013) used a signal detection paradigm to test White and Black participants' ability to discern well-documented incidents of racism (e.g., The FBI has employed illegal techniques such as hidden microphones in motels in an attempt to discredit African American political leaders during the civil rights movement) from fabricated incidents (e.g., The U.S. government deliberately created and administered the HIV virus to over 900 African Americans in a secret project during the 1980s). Better performance on the signal detection task indicated better attunement to historical reality, regardless of one's motivation to appear well-informed about past racism.

White People performed worse on the signal detection task, showing worse historical knowledge of past racism compared to Black People. This lack of 
historical knowledge, further, predicted White Peoples' lower perception of systemic racism (Bonam, Nair Das, Coleman, \& Salter, 2019; Nelson et al., 2013). Notably, even though this effect was stronger for people who saw their racial identity as more self-relevant, the effect held after controlling for racial identity relevance (Nelson et al., 2013). This finding suggests that although identity-defensive motivations may play a role in denial of racism, ignorance of historical reality is a key contributor to a lack of perception of racism.

\section{MICROAGGRESSION AS COVERT DISCRIMINATION}

Dominant groups may also fail to see discrimination because modern-day discrimination increasingly occurs in subtle forms rather than salient major events (Dovidio, 2001). Scholars from the perspective of critical race theory separate microaggression (verbal, behavioral, or environmental slights or insults directed toward a certain category of people) from macroaggression (institutional or structural discrimination) (Pérez Huber \& Solorzano, 2015; Sue, Capodilupo, et al., 2007; Williams, 2019). Unlike macroaggression, microaggressions can be enacted with or without intention. They are often brief, subtle, unacknowledged in the moment, albeit potentially insidious and pervasive.

Microaggressions have been classified into three categories: microassaults (derogatory epithets, e.g., "chinks"), microinsults (hidden insults demeaning a person's heritage or identity, e.g., saying "you couldn't have gotten this job" to a person of color), and microinvalidations (remarks that nullify a person's experiential reality, e.g., "you're being oversensitive") (Sue, Capodilupo, et al., 2007). Microinvalidations, in particular, can mask as compliments while negating a person's heritage. For example, Asian Americans who are U.S. citizens routinely receive remarks such as "Your English is really good!" and "Where are you really from?" These comments seem innocuous, but nullify one's American identity by assuming one as a perpetual foreigner (Sue, Bucceri, Lin, Nadal, \& Torino, 2007; Sue, Capodilupo, et al., 2007).

Microaggressions are often invisible to dominant group members (e.g., White People, men) (Lewis, 2017; Sue, Capodilupo, et al., 2007). Questions like "Where are you really from?" are commonly asked by well-intentioned White Americans, who lack the cognitive architecture to identify them as subtle acts of discrimination. In one study, we presented White and Asian Americans with a list of microaggression experiences routinely experienced by Asian Americans (e.g., being told their English is really good; being asked to help with math). We asked participants to judge, as fast as possible, whether each instance represented everyday discrimination. White People reacted more slowly than Asians, indicating a more impoverish schematic structure of and less cognitive access to microaggressions. This group difference in hypocognition predicted White Peoples' lack of awareness of White privilege as well as their lower perception of discrimination faced by Asians (vs White People) in the 2000s and 2010s.

Worse yet, microaggressions remain unnoticed and unaddressed because there is no easy way (for the perpetrator or the recipient) to disarm them after they 
have occurred (Sue et al., 2019). For recipients of microaggressions in particular, reacting in the moment incurs high social costs (Kaiser \& Miller, 2001) and risks being perceived as being hypersensitive (West, 2019). As such, recipients of microaggression typically "freeze" in the moment (Goodman, 2011), wish they could have spoken up after the moment has passed (Shelton, Richeson, Salvtore, $\&$ Hill, 2006), and are ridden with guilt and anxiety for their own paralysis (Sue et al., 2019).

\section{INTERVENTIONS: MAKING THE INVISIBLE VISIBLE}

If hypocognition of privilege blinds people to the disadvantages experienced by subordinate social groups, can reduction of hypocognition help increase awareness of discrimination? In our work, we design interventions that make visible the commonality of discrimination encountered by subordinate group members. In one intervention, we measured White and Asian American participants' baseline perception of discrimination against Asians versus White People from 1950s to 2010s (How much do you think White People [Asians] were/are subject to gender discrimination in the United States in each of the following decades? $1=$ not at all to $10=$ very much). About a week later, for the intervention group, we had White People and Asians learn the actual frequencies at which White People versus Asians experience various instances of everyday discrimination (e.g., being told jokes about the way people of your race talk). Actual frequencies were obtained from the responses of a separate sample from a similar population. In the control group, White People and Asians learned frequencies of instances unrelated to discrimination (e.g., being advised to drink eight cups of water per day). Participants then completed the same perceived discrimination measure as they did at baseline.

Postintervention, White People showed a significant increase in their perception of racial discrimination across the past seven decades. In particular, White Peoples' increased level of discrimination perception became similar to that of Asian Americans, which remained high before and after the intervention (Fig. 1).

In another intervention study, we showed male and female participants a TED talk of a transgender woman recounting her experience as a man (pretransition) and a woman (posttransition) versus a talk about productivity in the control condition. The procedure was similar to the previous intervention study, except the current intervention video did not include actual frequencies of gender discrimination and only introduced content of daily hassles encountered by women of which men may be hypocognitive. Findings demonstrated a significant increase in perception of gender discrimination against among men postintervention. Interestingly, women increased their perception of gender discrimination as well.

It is not only the replenishing of conceptual knowledge (e.g., content and prevalence of contemporary discrimination) that helps reduce group difference in the perception of discrimination. Learning about historical knowledge can also close the gap in perception of present-day racism. Bonam et al. (2019) had White 

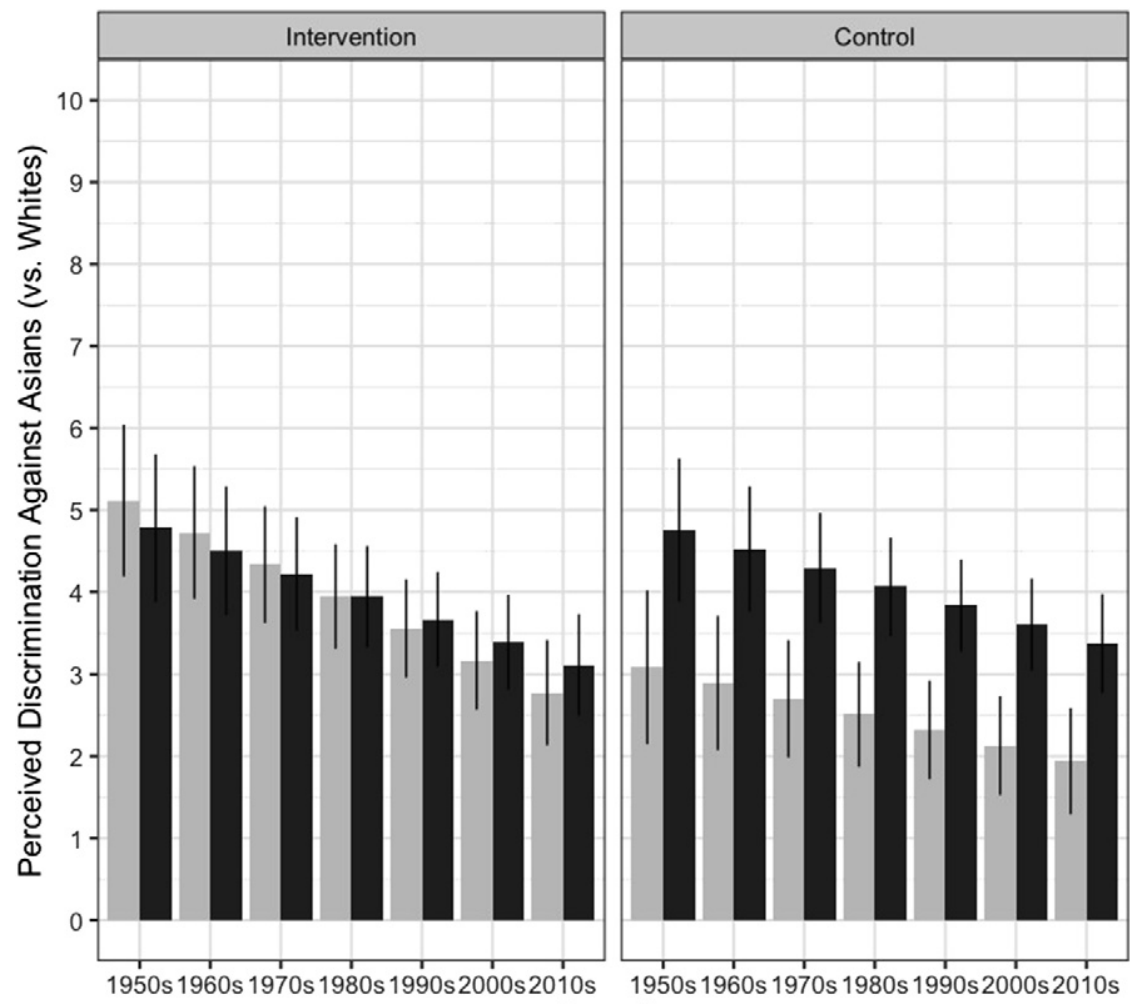

Decade

Participant Ethnicity

White

Fig. 1. The Effect of Intervention on Perceived Discrimination Against Asians (vs White People) from 1950s to 2010s among White and Asian Participants. Note: Error bars represent $+/-1$ standard error.

Americans listen to an excerpt on housing discrimination (vs pig intelligence in the control condition) from National Public Radio's program Fresh Air. The housing discrimination excerpt featured historian Richard Rothstein describing the role of discriminatory housing policy in creating U.S. ghettos. Learning about the history of housing discrimination helped boost perception about the prevalence of systemic racism.

More broadly, increasing the salience of societal racial discrimination can help increase accuracy in estimating racial economic equality. For example, after being asked to think about an "alternative US" rife with racial discrimination in education, law enforcement, employment, and voting rights, White Americans showed more tempered (and accurate) estimates of White/Black economic 
equality, compared to the overestimation of equality they reported when racial discrimination was not made salient (Kraus et al., 2017).

\section{Intersectionality}

Another intervention might be more indirect. People from dominant social groups often also possess subordinated identities. A White person may be female; a White man may be disabled (Coston \& Kimmel, 2012; Pratto \& Stewart, 2012). This intersectionality of social identities complicates the dichotomous understanding of privilege (Coston \& Kimmel, 2012). Rather than having privilege versus not, one can enjoy advantages in one social world while witnessing disadvantages in another. For a person belonging to a dominant social group, simultaneous membership in a subordinate group may grant the person some experience of what it means to be disadvantaged. In penning her White privilege checklist, Peggy McIntosh (1988), a White woman, recounted the reluctance of her male colleagues to acknowledge their male privilege. Being female made her aware of the invisibility of male privilege and led her to notice the phenomenon of White privilege, from which she benefitted and of which she was previously unaware.

Empirical work also shows that belonging to a subordinate position on one dimension of the social hierarchy helps increase perception of one's privilege along another dimension (Rosette \& Tost, 2013). White women (with the exception of those who have already achieved a high level of success), for example, are more likely to perceive their White privilege compared to White men. Likewise, racial minority men are more likely to perceive their male privilege than White men.

\section{Intergroup Contact}

Another way advantaged groups can gain awareness of privilege and discrimination is through intergroup contact (Pettigrew \& Tropp, 2006). One study examined whether extended intergroup contact through Teach for America, a national service organization, helped increase perception of class-based inequality and racial discrimination. College graduates who participated in Teach for America perceived greater class-based inequality and racial discrimination compared to those who did not participate (i.e., college graduates who were just below the selection cut-off for the program; Mo \& Conn, 2018). These effects persisted after six months to seven years postcompletion of the Teach for America program.

\section{DEFENSIVE MOTIVATIONS AND INTENTIONAL BLINDNESS}

It is one thing for advantaged groups to gain awareness of the extent of discrimination experienced by others; it is another to admit or accept that privilege exists. Even when privilege is made visible, people may employ 
strategies to "cloak" that privilege to address discomfort or assuage guilt around their privilege (Phillips, 2015; Phillips \& Lowery, 2018). For example, White People in the United States and United Kingdom claim more personal hardships when confronted with evidence of racial privilege than when not (Murdoch \& McAloney-Kocaman, 2019; Phillips \& Lowery, 2015). White People also cloak their privilege by minimizing the phenomenon of racism, doing so by conceiving of racism as individual rather than systemic, isolated rather than routine. Empirical work has shown that threat to self-image decreases White Peoples' acceptance of racism as systemic, and self-affirmation increases their willingness to conceive of racism as systemic (Unzueta \& Lowery, 2008). More broadly, advantaged groups often downplay acts of offense by conceiving them as one-off, isolated incidents, whereas disadvantaged groups view them as long lasting and systemic (Baumeister, Stillwell, \& Wotman, 1990; Zechmeister \& Romero, 2002).

With regard to our discussion on hypocognition, we have highlighted a cognitive or informational account for why dominant and subordinate groups may differ in their acknowledgment of privilege and in their beliefs about discrimination. However, we acknowledge that motivational dynamics can also come into play, particularly when people are explicitly confronted with privilege.

\section{COLOR BLINDNESS}

The data on defensive reactions suggest cautions on popular interventions suggested to address the hypocognition of privilege. A prevalent lay approach to navigating issues of racial privilege and race in general is avoiding the conversation altogether. Parents avoid talking about race with their children (Apfelbaum, Pauker, Ambady, Sommers, \& Norton, 2008), even though children are able to differentiate faces based on race from as early as six months (Bar-Haim, Ziv, Lamy, \& Hodes, 2006). White People set colorblind social policies and exclude topics of race from public discourse to avoid discussions of racial inequality (Chow \& Knowles, 2016). Conservative television host Tomi Lahren once proclaimed during a heated exchange with The Daily Show host Trevor Noah, "To me, true diversity is diversity of thought not diversity of color. I don't see color" (Hill, 2016).

This strategy of color blindness signifies the belief that racial group membership should not factor into decisions or behaviors (Apfelbaum, Norton, \& Sommers, 2012). After all, how can people or institutions be racist if they do not notice race in the first place? However, despite people's reluctance to notice race, people do notice race. People identify the race of a person rapidly and without conscious processing (Ito \& Urland, 2003; Montepare \& Opeyo, 2002), even though they are unwilling to admit so (Norton, Vandello, \& Darley, 2004). In one study, White American students were asked to either sort photos based on racial category (e.g., "White" vs "Black") or estimate how quickly they believe they would be able to categorize photos based on racial category. White People were much faster categorizing faces based on race than they said they would be (Norton, Sommers, Apfelbaum, Pura, \& Ariely, 2006). White People also avoid 
talking about race, even when they see it, in response to normative pressures. One study placed White participants in a photo identification task, in which they and their partners have to ask and answer questions about various dimensions (including race) to identify the photo. White People were less likely to bring up the race of the person in the photo if their partner chose a colorblind strategy (i.e., did not acknowledge race of the person in the photo). This reluctance in response to a colorblind norm was particularly strong if their partner was Black (vs White) (Apfelbaum, Sommers, \& Norton, 2008).

Ironically, expending effort to appear colorblind can backfire and incur social costs. The more White People avoid the mention of race, the more biased they appear in the eyes of Black observers (Apfelbaum, Sommers, et al., 2008). Reluctance to bring up race during photo identification is also associated with slower categorization and strained interracial interactions (e.g., decreased eye contact, less perceived friendliness; Norton et al., 2006).

More broadly, colorblind messages actually increase racial bias (Holoien \& Shelton, 2012; Richeson \& Nussbaum, 2004; Wolsko, Park, Judd, \& Wittenbrink, 2000) and provide justification for existing inequalities (Knowles, Lowery, Hogan, \& Chow, 2009). Emphasizing a common American identity (vs different racial group identities) decreases White Peoples' sensitivity to discrimination against Black People (Banfield \& Dovidio, 2013). In organizational settings, White employees' endorsement of colorblindness predicts their minority coworkers' lack of work engagement and greater perception of bias in the organizational climate (Plaut, Thomas, \& Goren, 2009). Thus, for people to be cognizant of their hypocognition, claiming not seeing color does not help; instead, it may perpetuate the status quo of racial hierarchies and blinds White People to their own privilege.

If colorblindness proves to be an ineffective strategy in addressing issues related to racial privilege, what alternative approaches are available? One approach focuses on multiculturalism, a pluralistic ideology that recognizes diversity and celebrates group differences (Apfelbaum et al., 2012). Unlike colorblindness, which focuses on common group identities and overlooks differences, multiculturalism appreciates intergroup commonalities while embracing distinctive qualities of the outgroup. Compared to colorblindness, multiculturalism fosters more positive intergroup interaction (Vorauer, Gagnon, \& Sasaki, 2009), increases accuracy in detection of discrimination (Apfelbaum, Pauker, Sommers, \& Ambady, 2010), and heightens motivation to engage in perspective-taking (Todd \& Galinsky, 2012). Importantly, the multiculturalism frame does not mute stereotypes about outgroups. In fact, one study showed that a multiculturalism (vs colorblind) message increased stereotyping of an outgroup; however, it simultaneously increased accuracy of such stereotypes and elicited positive regard of that group (Wolsko et al., 2000).

\section{CONCLUSION}

In 1959, White journalist John Howard Griffin had his skin temporarily darkened to live life as a Black man (Griffin, 1961). He embarked on a journey 
through the Deep South in dark skin, during the time of racial segregation. He received an onslaught of scorns, hate stares, racial slurs, and threats from White strangers. On occasion, some White People would offer him rides. However, he was astonished at how quickly they were to remark on stereotypes about Black People and gush about their fantasies of a "Negro" life. After a month, Griffin could no longer stand how he was treated and checked into a monastery. He wrote of this haunting experience, "Hell could be no more lonely or hopeless."

We no longer live in the age of Jim Crow, yet Griffin's experience may retain its significance. Journalist and writer Andrew Solomon

...once wished for himself: to be young and middle-aged, and perhaps even very old, all at the same time - and to be dark- and fair-skinned, deaf and hearing, gay and straight, male and female... to exploit all of the imagination's curious intricacies (Solomon, 2015)

Very few of us can traverse multiple social worlds in real life, but we can do so in imagination, in empathy, in listening to each other's stories, in peering into unfamiliar worlds. Until then, the experiences of differing social groups will remain unknown to each other, and the word "privilege" will stay a nebulous construct, a vacuous expression. Transgender people who have gone through a gender transition are often astounded at the challenges faced by the other gender - now that they live visibly as that other gender - and, at the same time, lament the gender privileges they have now lost. Perhaps it takes the experience of being paralyzed by ponderous difficulties to genuinely appreciate the lives of others. Perhaps it takes the fortitude of Griffin's transformation into a Black man to fully comprehend the hardship of living on the other side of the color line.

But it surely takes a lot more than "checking our privilege" to grasp the privilege of our own.

\section{REFERENCES}

Adams, G., Tormala, T. T., \& O’Brien, L. T. (2006). The effect of self-affirmation on perception of racism. Journal of Experimental Social Psychology, 42(5), 616-626. doi:10.1016/j.jesp.2005.11.001

Alba, J. W., \& Hasher, L. (1983). Is memory schematic? Psychological Bulletin, 93, 203-231.

Apfelbaum, E. P., Norton, M. I., \& Sommers, S. R. (2012). Racial color blindness: Emergence, practice, and implications. Current Directions in Psychological Science, 21(3), 205-209. doi: 10.1177/0963721411434980

Apfelbaum, E. P., Pauker, K., Ambady, N., Sommers, S. R., \& Norton, M. I. (2008). Learning (not) to talk about race: When older children underperform in social categorization. Developmental Psychology, 44(5), 1513-1518. doi:10.1037/a0012835

Apfelbaum, E. P., Pauker, K., Sommers, S. R., \& Ambady, N. (2010). In blind pursuit of racial equality? Psychological Science, 21(11), 1587-1592. doi:10.1177/0956797610384741

Apfelbaum, E. P., Sommers, S. R., \& Norton, M. I. (2008). Seeing race and seeming racist? Evaluating strategic colorblindness in social interaction. Journal of Personality and Social Psychology, 95(4), 918-932. doi:10.1037/a0011990

Banfield, J. C., \& Dovidio, J. F. (2013). Whites' perceptions of discrimination against Blacks: The influence of common identity. Journal of Experimental Social Psychology, 49(5), 833-841. doi: 10.1016/j.jesp.2013.04.008

Bar-Haim, Y., Ziv, T., Lamy, D., \& Hodes, R. M. (2006). Nature and nurture in own-race face processing. Psychological Science, 17(2), 159-163. doi:10.1111/j.1467-9280.2006.01679.x 
Barsalou, L. W. (1983). Ad hoc categories. Memory \& Cognition, 11(3), 211-227. doi:10.3758/ BF03196968

Bartlett, F. C. (1932). Remembering: A study in experimental and social psychology. New York, NY: Cambridge University Press.

Baumeister, R. E., Stillwell, A., \& Wotman, S. R. (1990). Victim and perpetrator accounts of interpersonal conflict: Autobiographical narratives about anger. Journal of Personality and Social Psychology, 59(5), 994-1005.

Black, L. L., \& Stone, D. (2005). Expanding the definition of privilege: The concept of social privilege. Journal of Multicultural Counseling and Development, 33(4), 243-255. doi:10.1002/j.21611912.2005.tb00020.x

Bleich, S. N., Findling, M. G., Casey, L. S., Blendon, R. J., Benson, J. M., SteelFisher, G. K., ... Miller, C. (2019). Discrimination in the United States: Experiences of Black Americans. Health Services Research, 54(2), 1399-1408. doi:10.1111/1475-6773.13220

Blendon, R. J., \& Casey, L. S. (2019). Discrimination in the United States: Perspectives for the future. Health Services Research, 54, 1467-1471. doi:10.1111/1475-6773.13218

Bonam, C. M., Nair Das, V., Coleman, B. R., \& Salter, P. (2019). Ignoring history, denying racism: Mounting evidence for the Marley hypothesis and epistemologies of ignorance. Social Psychological and Personality Science, 10(2), 257-265. doi:10.1177/1948550617751583

Brewer, W. F., \& Treyens, J. C. (1981). Role of schemata in memory for places. Cognitive Psychology, 13, 207-230.

Bullock, H. E. (1999). Attributions for poverty: A comparison of middle-class and welfare recipient attitudes. Journal of Applied Social Psychology, 29(10), 2059-2082. doi:10.1111/j.15591816.1999.tb02295.x

Chow, R. M., \& Knowles, E. D. (2016). Taking race off the table: Agenda setting and support for color-blind public policy. Personality and Social Psychology Bulletin, 42(1), 25-39. doi:10.1177/ 0146167215611637

Coston, B. M., \& Kimmel, M. (2012). Seeing privilege where it isn't: Marginalized masculinities and the intersectionality of privilege. Journal of Social Issues, 68(1), 97-111. doi:10.1111/j.15404560.2011.01738.x

Davidai, S., \& Gilovich, T. (2016). The headwinds/tailwinds asymmetry: An availability bias in assessments of barriers and blessings. Journal of Personality and Social Psychology, 111(6), 835-851. doi:10.1037/pspa0000066

Devos, T., \& Banaji, M. R. (2005). American = White? Journal of Personality and Social Psychology, 88(3), 447-466. doi:10.1037/0022-3514.88.3.447

DiAngelo, R. (2018). White fragility: Why it's so hard for White people to talk about racism. Boston, MA: Beacon Press.

Dietze, P., \& Knowles, E. D. (2016). Social class and the motivational relevance of other human beings: Evidence from visual attention. Psychological Science, 27(11), 1517-1527. doi:10.1177/ 0956797616667721

Dovidio, J. F. (2001). On the nature of contemporary prejudice: The third wave. Journal of Social Issues, 57(4), 829-849. doi:10.1111/0022-4537.00244

Egan Brad, L. C., Spisz, T. J., \& Tanega, C. G. (2018). Does “privilege checking” make us less racist, or more? Generation and political orientation matter. Race and Social Problems, 11, 1-14. doi: 10.1007/s12552-018-9246-0

Fairchild, K., \& Rudman, L. A. (2008). Everyday stranger harassment and women's objectification. Social Justice Research, 21(3), 338-357. doi:10.1007/s11211-008-0073-0

Feagin, J. R., \& Sikes, M. P. (1994). Living with racism: The black middle-class experience. Boston, MA: Beacon.

Fiske, S. T. (2001). Effects of power on bias: Power explains and maintains individual, group, and societal disparities. In A. Y. Lee-Chai \& J. A. Bargh (Eds.), The use and abuse of power: Multiple perspectives on the causes of corruption (pp. 181-193). London: Routledge.

Frank, R. H. (2016). Success and luck: Good fortune and the myth of meritocracy. Princeton, NJ: Princeton University Press. doi:10.1515/9781400880270

Galinsky, A. D., Magee, J. C., Ena Inesi, M., \& Gruenfeld, D. H. (2006). Power and perspectives not taken. Psychological Science, 17(12), 1068-1074. doi:10.1111/j.1467-9280.2006.01824.x 
Goodman, D. (2011). Promoting diversity and social justice: Educating people from privileged groups. New York, NY: Routledge.

Goodwin, S. A., Gubin, A., Fiske, S. T., \& Yzerbyt, V. Y. (2000). Power can bias impression processes: Stereotyping subordinates by default and by design. Group Processes \& Intergroup Relations, 3(3), 227-256. doi:10.1177/1368430200003003001

Griffin, J. H. (1961). Black like me. Boston, MA: Houghton Mifflin Harcourt.

Hall, J. A., Coats, E. J., \& LeBeau, L. S. (2005). Nonverbal behavior and the vertical dimension of social relations: A meta-analysis. Psychological Bulletin, 131(6), 898-924. doi:10.1037/00332909.131.6.898

Hegarty, P., \& Pratto, F. (2001). The effects of social category norms and stereotypes on explanations for intergroup differences. Journal of Personality and Social Psychology, 80(5), 723-735. doi: 10.1037/0022-3514.80.5.723

Henley, N. M. (1977). Body politics: Power, sex, and nonverbal communication. Englewood Cliffs, NJ: Prentice Hall.

Hill, J. (2016, December). Opinion: Dear "White Allies", stop saying that you "don't see color". $N B C$ News. Retrieved from https://www.nbcnews.com/news/nbcblk/opinion-dear-tomi-lahrenplease-stop-saying-you-dont-see-n690801

Holoien, D. S., \& Shelton, J. N. (2012). You deplete me: The cognitive costs of color blindness on ethnic minorities. Journal of Experimental Social Psychology, 48(2), 562-565. doi:10.1016/ j.jesp.2011.09.010

Ito, T. A., \& Urland, G. R. (2003). Race and gender on the brain: Electrocortical measures of attention to the race and gender of multiply categorizable individuals. Journal of Personality and Social Psychology, 85(4), 616-626. doi:10.1037/0022-3514.85.4.616

Kahneman, D., \& Miller, D. T. (1986). Norm theory: Comparing reality to its alternatives. Psychological Review, 93(2), 136-153. doi:10.1037/0033-295X.93.2.136

Kaiser, C. R., \& Miller, C. T. (2001). Stop complaining! the social costs of making attributions to discrimination. Personality and Social Psychology Bulletin, 27(2), 254-263. doi:10.1177/ 0146167201272010

Katz, J. (2006). The macho paradox: Why some men hurt women and how all men can help. Naperville, IL: Sourcebooks.

Knowles, E. D., Lowery, B. S., Hogan, C. M., \& Chow, R. M. (2009). On the malleability of ideology: Motivated construals of color blindness. Journal of Personality and Social Psychology, 96(4), 857-869. doi:10.1037/a0013595

Kraus, M. W., Côté, S., \& Keltner, D. (2010). Social class, contextualism, and empathic accuracy. Psychological Science, 21(11), 1716-1723. doi:10.1177/0956797610387613

Kraus, M. W., \& Keltner, D. (2009). Signs of socioeconomic status: A thin-slicing approach. Psychological Science, 20(1), 99-106. doi:10.1111/j.1467-9280.2008.02251.x

Kraus, M. W., Rucker, J. M., \& Richeson, J. A. (2017). Americans misperceive racial economic equality. Proceedings of the National Academy of Sciences, 114(39), 10324-10331. doi:10.1073/ pnas. 1707719114

Levy, R. I. (1973). Tahitians: Mind and experience in the society Islands. Chicago, IL: University of Chicago Press. doi:10.1016/j.cmet.2014.03.003

Lewis, J. A. (2017). From modern sexism to gender microaggressions: Understanding contemporary forms of sexism and their influence on diverse women. In C. B. Travis, J. W. White, A. E. Rutherford, W. S. Williams, \& S. L. Cook (Eds.), APA handbook of the psychology of women: History, theory, and battlegrounds. (Vol. 1, pp. 381-397). Washington, DC: American Psychological Association. doi:10.1037/0000059-019

McIntosh, P. (1988). White privilege and male privilege: A personal account of coming to see correspondences through work in women's studies. Wellesley College Center for Research on Women Working Paper No. 189. Retrieved from www.iub.edu/ tchsot1/part2/McIntosh $\% 20$ White $\% 20$ Privilege.pdf

McIntosh, P. (1989). White privilege: Unpacking the invisible knapsack. Peace and Freedom, 49, $10-12$. 
McMurtry, C. L., Findling, M. G., Casey, L. S., Blendon, R. J., Benson, J. M., Sayde, J. M., \& Miller, C. (2019). Discrimination in the United States: Experiences of Asian Americans. Health Services Research, 54(2), 1419-1430. doi:10.1111/1475-6773.13225

Miller, D. T., Taylor, B., \& Buck, M. L. (1991). Gender gaps: Who needs to be explained? Journal of Personality and Social Psychology, 61(1), 5-12. doi:10.1037/0022-3514.61.1.5

Mo, C. H., \& Conn, K. M. (2018). When do the advantaged see the disadvantages of others? A quasiexperimental study of national service. American Political Science Review, 112(4), 1016-1035. doi: $10.1017 /$ S0003055418000412

Montepare, J. M., \& Opeyo, A. (2002). The relative salience of physiognomic cues in differentiating faces: A methodological tool. Journal of Nonverbal Behavior, 26(1), 43-59. doi:10.1023/A: 1014470520593

Mullainathan, S., \& Shafir, E. (2013). Scarcity: Why having too little means so much. New York, NY: Times Books.

Murdoch, A., \& McAloney-Kocaman, K. (2019). Exposure to evidence of White Privilege and perceptions of hardships among White UK residents. Race and Social Problems, 11(3), 205-211. doi:10.1007/s12552-019-09262-3

Neisser, U. (1976). Cognition and reality: Principles and implications of cognitive psychology. New York, NY: W. H. Freeman.

Nelson, J. C., Adams, G., \& Salter, P. S. (2013). The Marley hypothesis: Denial of racism reflects ignorance of history. Psychological Science, 24(2), 213-218. doi:10.1177/0956797612451466

Norton, M. I., \& Sommers, S. R. (2011). Whites see racism as a zero-sum game that they are now losing. Perspectives on Psychological Science, 6(3), 215-218. doi:10.1177/1745691611406922

Norton, M. I., Sommers, S. R., Apfelbaum, E. P., Pura, N., \& Ariely, D. (2006). Color blindness and interracial interaction: Playing the political correctness game. Psychological Science, 17(11), 949-953. doi:10.1111/j.1467-9280.2006.01810.x

Norton, M. I., Vandello, J. A., \& Darley, J. M. (2004). Casuistry and social category bias. Journal of Personality and Social Psychology, 87(6), 817-831. doi:10.1037/0022-3514.87.6.817

Pérez Huber, L., \& Solorzano, D. G. (2015). Racial microaggressions as a tool for critical race research. Race, Ethnicity and Education, 18(3), 297-320. doi:10.1080/13613324.2014.994173

Pettigrew, T. F., \& Tropp, L. R. (2006). A meta-analytic test of intergroup contact theory. Journal of Personality and Social Psychology, 90(5), 751-783. doi:10.1037/0022-3514.90.5.751

Pew Research Center. (2016). On views of race and inequality, Blacks and Whites are worlds apart. Retrieved from http://assets.pewresearch.org/wp-content/uploads/sites/3/2016/06/ST_2016.06.27_ Race-Inequality-Final.pdf

Pew Research Center. (2017). Wide partisan gaps in U.S. over how far the country has come on gender equality. Retrieved from http://www.pewsocialtrends.org/2017/10/18/wide-partisan-gaps-in-u-sover-how-far-the-country-has-come-on-gender-equality/

Pew Research Center. (2019, April 9). Race in America 2019. Retrieved from https:// www.pewsocialtrends.org/wp-content/uploads/sites/3/2019/04/Race-report_updated-4.29.19.pdf

Phillips, L. T. (2015). I ain't no fortunate one: On the motivated denial of class and race privilege. Academy of Management Proceedings, 2015(1), 19158.

Phillips, L. T., \& Lowery, B. S. (2015). The hard-knock life? Whites claim hardships in response to racial inequity. Journal of Experimental Social Psychology, 61, 12-18. doi:10.1016/ j.jesp.2015.06.008

Phillips, L. T., \& Lowery, B. S. (2018). Herd invisibility: The psychology of racial privilege. Current Directions in Psychological Science, 27(3), 156-162. doi:10.1177/0963721417753600

Pinterits, E. J., Poteat, V. P., \& Spanierman, L. B. (2009). The White privilege attitudes scale: Development and initial validation. Journal of Counseling Psychology, 56(3), 417-429. doi: 10.1037/a0016274

Plaut, V. C., Thomas, K. M., \& Goren, M. J. (2009). Is multiculturalism or color blindness better for minorities?: Short report. Psychological Science, 20(4), 444 446. doi:10.1111/j.14679280.2009.02318.x

Pratto, F. (1991). The puzzle of continuing group inequality: Piecing together psychological, social, and cultural forces in social dominance theory. In M. P. Zanna (Ed.), Advances in experimental 
social psychology (Vol. 31, pp. 191-263). San Diego, CA: Academic Press. doi:10.1016/ S0065260108602749

Pratto, F., Hegarty, P. J., \& Korchmaros, J. D. (2008). Who gets stereotyped? How communication practices and category norms lead people to stereotype particular people and groups. In Y. Kashima, K. Fiedler, \& P. Freytag (Eds.), Stereotype dynamics (pp. 299-319). Mahwah, NJ: Lawrence Erlbaum Publishers. Retrieved from https://books.google.it/books?hl=it\&lr=\&id=NsJ6us ws9rQC\&oi=fnd\&pg =PA293\&dq=Devos,T.,\%26Banaji,M.(2005).American\%3DWhite\%3FJournal InalofPersonalityandSocialPsychology, +88,+447-\&ots=466.GqYMcumgnY\&sig=leRvHejfQhJD_x zmW2my7v59WSY

Pratto, F., \& Stewart, A. L. (2012). Group dominance and the half-blindness of privilege. Journal of Social Issues, 68(1), 28-45. doi:10.1111/j.1540-4560.2011.01734.x

Richeson, J. A., \& Nussbaum, R. J. (2004). The impact of multiculturalism versus color-blindness on racial bias. Journal of Experimental Social Psychology, 40(3), 417-423. doi:10.1016/ j.jesp.2003.09.002

Rosette, A. S., \& Tost, L. P. (2013). Perceiving social inequity: When subordinate-group positioning on one dimension of social hierarchy enhances privilege recognition on another. Psychological Science, 24(8), 1420-1427. doi:10.1177/0956797612473608

Shelton, J. N., Richeson, J. A., Salvtore, J., \& Hill, D. M. (2006). Silence is not golden: The intrapersonal consequences of not confronting prejudice. In S. Levin \& C. Van Laar (Eds.), Stigma and group inequality: Social psychological perspectives. Mahwah, NJ: Psychology Press

Sidanius, J., \& Pratto, F. (1999). Social hierarchy and asymtrical group behavior. In J. Sidanius \& F. Pratto (Eds.), Social dominance: An intergroup theory of social hierarchy and oppression (pp. 227-262). New York, NY: Cambridge University Press.

Solomon, A. (2015, March). The middle of things: Advice for young writers. The New Yorker. Retrieved from http:/www.newyorker.com/books/page-turner/the-middle-of-things-advice-foryoung-writers $\% 5 \mathrm{Cnhttp} / /$ worldvoices.pen.org/speech/middle-things-advice-young-writers

SteelFisher, G. K., Findling, M. G., Bleich, S. N., Casey, L. S., Blendon, R. J., Benson, J. M., \& Miller, C. (2019). Gender discrimination in the United States: Experiences of women. Health Services Research, 54(2), 1442-1453. doi:10.1111/1475-6773.13217

Stellar, J. E., Manzo, V. M., Kraus, M. W., \& Keltner, D. (2012). Class and compassion: Socioeconomic factors predict responses to suffering. Emotion, 12(3), 449-459. doi:10.1037/a0026508

Strickhouser, J. E., Zell, E., \& Harris, K. E. (2018). Ignorance of history and perceptions of racism. Social Psychological and Personality Science, 10(7), 977-985. doi:10.1177/1948550618808863

Sue, D. W., Alsaidi, S., Awad, M. N., Glaeser, E., Calle, C. Z., \& Mendez, N. (2019). Disarming racial microaggressions: Microintervention strategies for targets, White allies, and bystanders. American Psychologist, 74(1), 128-142. doi:10.1037/amp0000296

Sue, D. W., Bucceri, J., Lin, A. I., Nadal, K. L., \& Torino, G. C. (2007). Racial microaggressions and the Asian American experience. Cultural Diversity and Ethnic Minority Psychology, 13(1), 72-81. doi:10.1037/1948-1985.S.1.88

Sue, D. W., Capodilupo, C. M., Torino, G. C., Bucceri, J. M., Holder, A. M. B., Nadal, K. L., \& Esquilin, M. (2007). Racial microaggressions in everyday life: Implications for clinical practice. American Psychologist, 62(4), 271-286. doi:10.1037/0003-066X.62.4.271

Todd, A. R., \& Galinsky, A. D. (2012). The reciprocal link between multiculturalism and perspectivetaking: How ideological and self-regulatory approaches to managing diversity reinforce each other. Journal of Experimental Social Psychology, 48(6), 1394-1398. doi:10.1016/ j.jesp.2012.07.007

Unzueta, M. M., \& Lowery, B. S. (2008). Defining racism safely: The role of self-image maintenance on White Americans' conceptions of racism. Journal of Experimental Social Psychology, 44(6), 1491-1497. doi:10.1016/j.jesp.2008.07.011

Vorauer, J., Gagnon, A., \& Sasaki, S. (2009). Salient intergroup ideology and intergroup interaction. Psychological Science, 20(7), 838-845. Retrieved from http://pss.sagepub.com.proxy.lib.umich. edu/content $/ 20 / 7 / 838$. short

West, K. (2019). Testing hypersensitive responses: Ethnic minorities are not more sensitive to microaggressions, they just experience them more frequently. Personality and Social Psychology Bulletin, 45(11), 1619-1632. doi:10.1177/0146167219838790 
Williams, M. T. (2019). Microaggressions: Clarification, evidence, and impact. Perspectives on Psychological Science. 15(1), 3-26. doi:10.1177/1745691619827499

Wise, T. (2006, April 24). What kind of card is race? The absurdity (and consistency) of White Denial. Counterpunch. Retrieved from http://www.counterpunch.org/2006/04/24/what-kind-of-card-israce

Wolsko, C., Park, B., Judd, C. M., \& Wittenbrink, B. (2000). Framing interethnic ideology: Effects of multicultural and color-blind perspectives on judgments of groups and individuals. Journal of Personality and Social Psychology, 78(4), 635-654. doi:10.1037/0022-3514.78.4.635

Wu, K., \& Dunning, D. (2018). Hypocognition: Making sense of the landscape beyond one's conceptual reach. Review of General Psychology, 22(1), 25-35. doi:10.1037/gpr0000126

Wu, K., \& Dunning, D. (2019). Hypocognitive mind: How lack of conceptual knowledge confines what people see and remember. Unpublished manuscript. University of Michigan doi:10.31234/ osf.io/29ryz

Zechmeister, J. S., \& Romero, C. (2002). Victim and offender accounts of interpersonal conflict: Autobiographical narratives of forgiveness and unforgiveness. Journal of Personality and Social Psychology, 82(4), 675-686. doi:10.1037/0022-3514.82.4.675 